\title{
Analisis Kepuasan Kerja Karyawan Berdasarkan Kompensasi dan Motivasi Kerja Pada CV. Abata
}

\author{
Tri Darmawati \\ Dosen Fakultas Ekonomi Universitas PGRI Palembang \\ email: tridarmawati@univpgri-palembang.ac.id
}

\begin{abstract}
ABSTRAK
Penelitian ini bertujuan untuk mengetahui pengaruh kompensasi dan motivasi kerja terhadap kepuasan kerja karyawan baik secara parsial maupun secara bersama-sama. Metode penelitian yang digunakan adalah metode deskriptif dengan pendekatan kuantitatif. Populasi dan sampel menggunakan metode sampling jenuh yaitu seluruh karyawan CV. Abata sebanyak 40 orang. Teknik pengumpulan data menggunakan teknik dokumentasi dan kuisioner. Teknik analisa data yang digunakan adalah analisis regresi linear sederhana, analisis regresi linear berganda, uji t dan uji $\mathrm{f}$. Adapun hasil uji t penelitian ini untuk variabel kompensasi secara parsial diperoleh nilai thitung 1,746 dengan tabel 1,685 maka dapat disimpulkan bahwa terdapat pengaruh positif dan signifikan kompensasi terhadap kepuasan kerja pada karyawan CV. Abata, sedangkan untuk variabel motivasi kerja secara parsial diperoleh thitung sebesar 2,388 dengan ttabel 1,685 maka dapat disimpulkan terdapat pengaruh positif dan signifikan motivasi kerja terhadap kepuasan kerja pada karyawan CV. Abata. Hasil uji $f$ untuk variabel kompensasi dan motivasi secara bersama-sama diperoleh $f_{\text {hitung }}$ sebesar 3,831 dengan $f_{\text {tabel }}$ 3,24 maka dapat disimpulkan bahwa terdapat pengaruh positif dan signifikan secara bersama-sama kompensasi dan motivasi kerja terhadap kepuasan kerja pada karyawan CV. Abata.
\end{abstract}

Kata kunci : kompensasi, motivasi kerja dan kepuasan kerja

I. Pendahuluan

Salah satu modal penting dalam pengelolaan organisasi atau perusahaan adalah sumber daya manusia, karena perannya sebagai subjek pelaksana kebijakan dan kegiatan operasional organisasi atau perusahaan. Sumber daya yang dimiliki oleh perusahaan seperti modal, metode dan mesin tidak bisa memberikan hasil yang optimal apabila tidak didukung oleh sumber daya manusia yang mempunyai kinerja yang optimal. Untuk mendapatkan hasil kinerja yang optimal sumber daya manusia harus dikelola dan diatur dengan sebaik mungkin, sehingga sumber daya manusia dalam sebuah perusahaan merasa nyaman dalam menjalankan tugasnya dan mendapatkan hasil yang maksimal. Pengelolaan sumber daya manusia yang dimaksudkan adalah bahwa perusahaan harus mampu untuk menyatukan persepsi atau cara pandang pegawai dan pimpinan organisasi atau perusahaan dalam rangka mencapai tujuan perusahaan antara lain melalui pembentukan mental bekerja yang baik dengan dedikasi dan loyalitas yang tinggi terhadap pekerjaannya, memberikan motivasi kerja, kompensasi, bimbingan, pengarahan dan koordinasi yang baik dalam bekerja oleh seorang pemimpin kepada bawahannya dalam usaha menciptakan menciptakan kepuasan kerja karyawan.

Untuk itu menjadi tantangan pimpinan organisasi atau perusahaan dalam meningkatkan kualitas sumber daya manusia sehingga siap menghadapi tantangan pekerjaan yang semakin rumit. Ada beberapa faktor yang mempengaruhi peningkatan kualitas kerja karyawan yaitu diantaranya kompensasi, motivasi kerja dan kepuasan kerja. Terdapat hubungan positif dan signifikan antara motivasi kerja dengan kinerja (Haryono, 
2017). Gray mendefinisikan motivasi sebagai hasil sejumlah proses yang bersifat internal atau eksternal bagi bagi seorang individu, yang menyebabkan timbulnya sikap antusiasme dan persistensi dalam hal melaksanakan kegiatan kegiatan tertentu (Yusuf, 2015). Menurut Handoko yang dimaksud dengan kompensasi adalah segala sesuatu yang diterima oleh karyawan sebagai balas jasa untuk kerja mereka (Sutrisno, 2017). Menurut Gibson menyatakan bahwa kepuasan kerja sebagai sikap yang dimiliki pekerja tentang pekerjaan yang dilakukan (Yusuf, 2015).

CV. Abata merupakan perusahaan yang bergerak dibidang jasa konstruksi dan pengadaan barang dan jasa. Untuk itu diperlukan tenaga sumber daya manusia yang berkualitas dengan harapan bisa memenuhi ekspektasi yang diinginkan oleh konsumen. Seperti yang diuraikan diatas beberapa faktor yang mempengaruhi kualitas kerja adalah kompensasi, motivasi dan kepuasan kerja. Berdasarkan uraian di atas maka penulis merumuskan permasalahan sebagai berikut:
1. Apakah terdapat pengaruh kompensasi terhadap kepuasan kerja pada karyawan CV. Abata?

2. Apakah terdapat pengaruh motivasi kerja terhadap kepuasan kerja pada karyawan CV. Abata?

3. Apakah terdapat pengaruh kompensasi dan motivasi kerja secara bersama-sama terhadap kepuasan kerja pada karyawan CV. Abata?

\section{Kompensasi}

Kompensasi adalah semua pendapatan yang berbentuk uang, barang langsung atau tidak langsung yang diterima karyawan sebagai imbalan atas jasa yang diberikan pada perusahaan (Hasibuan, 2012). Kompensasi adalah sesuatu yang diterima karyawan atas jasa yang mereka sumbangkan pada pekerjaannya (Wilson, 2012). Menurut Marithot kompensasi adalah keseluruhan balas jasa yang diterima oleh pegawai sebagai akibat dari pelaksanaan pekerjaan di organisasi dalam bentuk uang atau lainnya, yang dapat berupa gaji, upah, bonus, insentif, dan tunjangan lainnya seperti tunjangan kesehatan, tunjangan hari raya, uang makan, uang cuti, dan lainlain (Yusuf, 2015). Menurut Singodimedjo kompensasi dapat diberikan dalam berbagai macam bentuk seperti dalam bentuk pemberian uang secara langsung, pemberian Material dan fasilitas, dan dalam bentuk pemberian kesempatan berkarier (Sutrisno, 2017). Kompensasi merupakan kontra prestasi terhadap penggunaan tenaga atau jasa yang telah diberikan oleh tenaga kerja dan jumlah paket yang ditawarkan organisasi kepada pekerja sebagai imbalan atas penggunaan tenaga kerjanya (Wibowo, 2016). Kompensasi merupakan salah satu aspek yang berarti bagi karyawan, karena individu/karyawan besarnya kompensasi mencerminkan ukuran nilai karya diantara para karyawan itu sendiri, keluarga dan masyarakat (Hamali, 2018). Pemberian kompensasi dalam suatu organisasi dapat berfungsi sebagai berikut:

1. Pengalokasian sumber daya manusia secara efisien. fungsi ini menunjukkan pemberian kompensasi pada karyawan yang berprestasi akan mendorong mereka untuk bekerja lebih baik.

2. Penggunaan sumber daya manusia secara lebih efisien dan efektif. Dengan pemberian kompensasi kepada karyawan mengandung implikasi bahwa organisasi akan 
menggunakan tenaga karyawan dengan efisien dan efektif.

3. Mendorong stabilitas dan pertumbuhan ekonomi. Sistem pemberian kompensasi dapat membantu stabilisasi organisasi dan mendorong pertumbuhan ekonomi secara keseluruhan (Yusuf, 2015).

\section{Sedangkan}

pemberian kompensasi didalam suatu perusahaan memiliki tujuan sebagai berikut:

1. Pemenuhan kebutuhan ekonomi. karyawan menerima kompensasi berupa upah, gaji ataau bentuk lainnya untuk dapat memenuhi kebutuhan hidupnya sehari hari atau dengan kata lain, kebutuhan ekonominya. Dengan adanya kepastian menerima upah atau gaji, tersebut secara periodik, berarti adanya jaminan economic security bagi dirinya dan keluarga yang menjadi tanggungannya.

2. Meningkatkan produktivitas kerja. Pemberian kompensasi yang makin baik akan mendorong karyawan bekerja secara produktif.

3. Memajukan organisasi atau perusahaan. Semakin berani suatu perusahaan memberikan kompensasi yang tinggi, semakin menunjukkan betapa semakin sukses nya suatu perusahaan, sebab pemberian kompensasi yang tinggi hanya mungkin apabila pendapatan perusahaan yang digunakan untuk itu semakin besar.

4. Menciptakan keseimbangan dan keadilan. Ini berarti bahwa pemberian kompensasi berhubungan dengan persyaratan yang harus dipenuhi oleh karyawan pada jabatan sehingga tercipta keseimbangan (Yusuf, 2015).

Kompensasi terbagi 2 yaitu:

1. Kompensasi bersifat normatif, adalah kompensasi minimun yang harus diterima yang terdiri gaji atau upah (termasuk didalamnya gaji/upah pokok, tunjangan tetap) dan komponen tetap lainnya seperti tunjangan kesehatan, dan tunjangan hari raya.

2. Kompensasi bersifat kebijakan, adalah kompensasi yang didasari kebijakan dan atau karena pertimbangan khusus, seperti tunjangan profesional, tunjangan makan dan transport, bonus, uang cuti, jasa produksi dan libuiran (Edison, 2016).

Besar kecilnya pemberian kompensasi tidak mungkin dapat ditentukan begitu saja, tanpa mengantisipasi perkembangan keadaan sekitar yang mengelilingi gerak perusahaan. Ada beberapa faktor faktor yang mempengaruhi besarnya kompensasi yaitu:

1. Tingkat biaya hidup.

2. Tingkat kompensasi yang berlaku di perusahaan lain.

3. Tingkat kemampuan perusahaan.

4. Jenis pekerjaan dan besar kecilnya tanggung jawab.

5. Peraturan perundang undangan yang berlaku.

6. Peranan serikat buruh (Sutrisno, 2017).

Berdasarkan pendapat beberapa para ahli diatas dapat disimpulkan kompensasi adalah balas jasa yang diterima oleh karyawan berupa upah, gaji, bonus, insentif, fasilitas kesehatan dan lainnya sebagai imbalan terhadap penggunaan tenaga atau jasa yang telah diberikan oleh tenaga kerja. Adapun indikator kompensasi adalah: tingkat biaya hidup, tingkat kompensasi yang berlaku di perusahaan lain, tingkat kemampuan perusahaan, jenis pekerjaan dan besar kecilnya tanggung jawab, peraturan perundang-undangan yang berlaku dan peranan serikat buruh. 


\section{Motivasi}

Motivasi berasal dari kata "motif" yang diartikan sebagai daya penggerak yang telah menjadi aktif (Sardiman, 2005). Motivasi adalah pernyataan yang kompleks didalam suatu organisme yang mengarahkan tingkah laku terhadap suatu tujuan atau perangsang (Purwanto, 2002). Sedangkan menurut Greeberg dan Baron berpendapat bahwa motivasi merupakan serangkaian proses yang membangkitkan, mengarahkan, dan menjaga perilaku manusia menuju pada pencapaian tujuan (Wibowo, 2016). Motivasi adalah keinginan untuk melakukan sebagai kesediaan untuk mengeluarkan tingkat upaya yang tinggi untuk tujuan-tujuan organisasi, yang dikondisikan oleh kemampuan upaya itu untuk memenuhi suatu kebutuhan individual (Robbins, 2002). Motivasi kerja ini secara operasional diukur dengan menggunakan 3 (tiga) indikator, yaitu: kebutuhan berprestasi, kebutuhan fisik, dan kebutuhan rasa aman (Brahmasari, 2008).

Teori motivasi menurut Maslow, model ini sering disebut dengan model hirarki kebutuhan, karena menyangkut kebutuhan manusia, maka teori ini digunakan untuk menunjukkan kebutuhan seseorang yang harus dipenuhi agar individu tersebut termotivasi untuk bekerja (Noor, 2013). Teori ini mendasarkan pada faktorfaktor kebutuhan dan kepuasan individu sehingga mereka mau melakukan aktivitasnya. Teori ini mencoba mencari tahu tentang kebutuhan apa yang dapat memuaskan dan yang mendorong semangat kerja seseorang. Semakin tinggi kebutuhan dan kepuasaan seseorang, semakin tinggi standar kebutuhan dan kepuasan yang diinginkan, maka semakin giat seseorang untuk bekerja. Adapun kebutuhan manusia terdiri dari beberapa tingkatan dengan urutan sebagai berikut:

1. Kebutuhan fisiologis Misalnya makanan, minuman, istirahat/tidur.

2. Kebutuhan rasa aman adalah kebutuhan atas perlindungan dari gangguan pihak lain baik yang berasal dari manusia lain maupun dari makhluk lain seperti binatang buas dan sebagainya.

3. Kebutuhan sosial adalah berupa kebutuhan untuk bergaul dengan manusia lain atau anggota masyarakat yang lain. Kebutuhan ini dapat berupa memberi dan menerima rasa cinta kasih, rasa diterima dalam kelompok, rasa membutuhkan dan dibutuhkan, rasa berteman atau bekerja sama.

4. Kebutuhan self esteem (harga diri) adalah kebutuhan akan rasa harga diri, setelah tiga kebutuhan diatas telah terpenuhi maka akan muncul kebutuhan harga diri berupa: kebutuhan akan rasa percaya diri, kekuatan, penguasaan, kompetensi, kemandirian yang berasal dari dalam diri seseorang. Sedangkan yang berasal dari luar adalah kebutuhan akan penghargaan/apresiasi dari orang lain, status ketenaran, kebanggaan, bahkan dominasi. Jika seseorang telah terpenuhi kebutuhan akan rasa harga dirinya maka ia akan menjadi pribadi yang mandiri, percaya diri, dan menyiapkan dirinya untuk kebutuhan selanjutnya yang lebih tinggi.

5. Kebutuhan aktualisasi diri, yakni senantiasa percaya kepada diri sendiri. Pada puncak hirarki, terdapat kebutuhan untuk realisasi diri, atau aktualisasi diri. Kebutuhankebutuhan tersebut berupa individu untuk merealisasi potensi yang ada pada dirinya, untuk mencapai pengembangan diri secara 
berkelanjutan, untuk menjadi kreatif (Noor, 2013).

Berdasarkan pendapat beberapa para ahli diatas dapat disimpulkan motivasi kerja adalah serangkaian proses membangkitkan, mengarahkan dorongan dari perilaku yang disebabkan kebutuhan, keinginan, kemauan, sehingga orang tersebut melakukan tindakan demi tercapainya tujuan. Adapun indikator motivasi kerja adalah: kebutuhan berprestasi, kebutuhan fisik dan kebutuhan arasa aman.

\section{Kepuasan Kerja}

Kepuasan kerja adalah keadaan emosional yang menyenangkan atau tidak menyenangkan dimana para pegawai memandang pekerjaannya (Yusuf, 2015). Kepuasan kerja mencerminkan perasaan seseorang terhadap pekerjaannya. Hal ini tampak pada sikap positif pegawai terhadap pekerjaan dan segala sesuatu yang dihadapi dilingkungan kerjanya. Kepuasan kerja merupakan sikap positif tenaga kerja tehadap pekerjaannya, yang timbul berdasarkan penilaian terhadap situasi kerja (Hamali, 2018). Kepuasaan kerja adalah sikap umum terhadap pekerjaan seseorang,yang menunjukkan perbedaaan antara jumlah penghargaan yang diterima pekerja dan jumlah yang mereka yakini yang seharusnya mereka terima (Wibowo, 2016).Teori kepuasan kerja mencoba mengungkapkan apa yang membuat sebagian orang lebih puas terhadap pekerjaannya daripada beberapa lainnya. teori ini juga mencari landasan tentang proses perasaan orang terhadap kepuasan kerja.

Ada beberapa teori kepuasan kerja yaitu:
1. Two-Factor Theory, yaitu teori dua faktor merupakan teori kepuasan kerja yang menganjurkan bahwa satisfaction (kepuasan) dan dissatisfaction (ketidakpuasan) merupakan bagian dari kelompok variabel yang berbeda, yaitu motivators dan hygiene factor. Pada umumnya orang mengharapkan bahwa faktor tertentu memberikan kepuasan apabila tersedia dan menimbulkan ketidakpuasan apabila tidak ada. Pada teori ini, ketidakpuasan dihubungkan dengan kondisi di sekitar pekerjaan (seperti kondisi kerja, pengupahan, keamanan, kualitas, pengawasan, dan hubungan dengan orang lain), dan bukannya dengan pekerjaan itu sendiri. Karena faktor ini mencegah reaksi negatif, dinamakan sebagai hygiene atau maintenance factors. Sebaliknya, kepuasan ditarik dari faktor yang terkait dengan pekerjaan itu sendiri atau hasil langsung daripadanya, seperti sifat pekerjaan, prestasi dalam pekerjaan, peluang promosi dan kesempatan untuk pengembangan diri dan pengakuan.

2. Value theory, menurut konsep ini kepuasan kerja terjadi pada tingkatan dimana hasil pekerjaan diterima individu seperti diharapkan. Semakin banyak orang menerima hasil, akan semakin puas. Semakin sedikit mereka menerima hasil, akan kurang puas. Value theory memfokuskan pada hasil mana pun yang menilai orang tanpa memperhatikan siapa mereka. Kunci menuju kepuasan dalam pendekatan ini adalah perbedaan antara aspek pekerjaan yang dimiliki dan diinginkan seseorang. semakin besar perbedaan, semakin rendah kepuasan orang (Wibowo, 2016). 
Implikasi teori ini mengundang perhatian pada aspek pekerjaan yang perlu diubah untuk mendapatkan kepuasan kerja. Secara khusus teori ini menganjurkan bahwa aspek tersebut tidak harus sama berlaku untuk semua orang, tetapi mungkin aspek nilai dari pekerjaan tentang orang yang merasakan. Dengan menekankan pada nilai nilai, teori ini menganjurkan bahwa kepuasan kerja dapat diperoleh dari banyak faktor. Oleh karena itu, cara yang efektif untuk memuaskan pekerjaan adalah dengan menemukan apa yang mereka inginkan dan apabila mungkin memberikannya. Banyak Faktor yang mempengaruhi kepuasan kerja karyawan. Faktor faktor itu sendiri dalam peranannya memberikan kepuasan kepada karyawan bergantung pada pribadi masing masing karyawan. Menurut Blum, faktor-faktor yang memberikan kepuasan dalam adalah:

1. Faktor Individual, meliputi umur, kesehatan, watak, dan harapan.

2. Faktor sosial, Meliputi hubungan kekeluargaan, pandangan pekerjaan, kebebasan berpolitik, dan hubungan masyarakat.

3. Faktor utama dalam pekerjaan, meliputi upah, pengawasan, ketentraman kerja, kondisi kerja dan kesempatan untuk maju. Selain itu, juga penghargaan terhadap kecakapan, hubungan sosial didalam pekerjaan, ketepatan dalam menyelesaikan konflik antar manusia, perasaan diperlakukan adil baik yang menyangkut pribadi maupun tugas (Sutrisno, 2017).

Kepuasan kerja karyawan ini secara operasional diukur dengan menggunakan 4 (empat) indikator yang diadopsi dari teori dua faktor Herzberg, yaitu: (1) Kompensasi, (2) Kondisi kerja, (3) Sistem administrasi dan kebijakan perusahaan,
Kesempatan untuk berkembang (Mangkunegara, 2005). Sedangkan menurut Gilmer, faktor-faktor yang mempengaruhi kepuasan kerja adalah kesempatan untuk maju, keamanan kerja, gaji, perusahaan, pengawasan, faktor intrinsik dari pekerjaan, kondisi kerja, aspek sosial dalam pekerjaan, komunikasi dan fasilitas (Sutrisno, 2017).

Berdasarkan pendapat beberapa para ahli diatas dapat disimpulkan kepuasan kerja adalah keadaan emosional pegawai dalam memandang pekerjaannya yang timbul berdasarkan penilaian kerja. Adapun indikator kepuasan kerja adalah: kompensasi, kondisi kerja, sistem administrasi dan kebijakan perusahaan, kesempatan untuk berkembang.

\section{Metode Penelitian}

Variabel dalam penelitian ini terdiri dari variabel bebas yaitu kompensasi (X1), motivasi kerja (X2) dan variabel terikat yaitu kepuasan kerja (Y). Metode penelitian yang digunakan adalah metode deskriptif dengan pendekatan kuantitatif. Populasi adalah generalisasi yang terdiri dari objek atau subjek yang mempunyai kualitas dan karakteristik tertentu yang ditetapkan oleh peneliti untuk dipelajari kemudian ditarik kesimpulanya (Sudaryono, 2017). Populasi dan sampel menggunakan metode sampling jenuh yaitu seluruh karyawan CV. Abata sebanyak 40 orang. Sampel adalah bagian dari jumlah dan karakteristik yang dimiliki oleh Populasi tersebut (Sugiyono, 2017). Teknik pengumpulan data menggunakan teknik dokumentasi dan kuisioner. Kuisioner merupakan teknik pengumpulan data yang dilakukan dengan cara memberikan seperangkat pertanyaan atau pernyataan tertulis kepada responden untuk dijawabnya (Sugiyono, 2017). Metode ini dilakukan 
dengan memberi sejumlah pertanyaan yang berkaitan dengan kepuasan kerja pegawai.

Kerangka berfikir merupakan model konseptual tentang bagaimana teori berhubungan dengan berbagai faktor yang telah diidentifikasi sebagai masalah yang penting (Sugiyono,
2017). Kerangka berfikir yang baik akan menjelaskan secara teoritis pertautan antar variabel yang akan diteliti. Jadi secara teoritis perlu dijelaskan hubungan antar variabel independen dan dependen.

Kerangka pemikiran dalam penelitian ini adalah sebagai berikut :

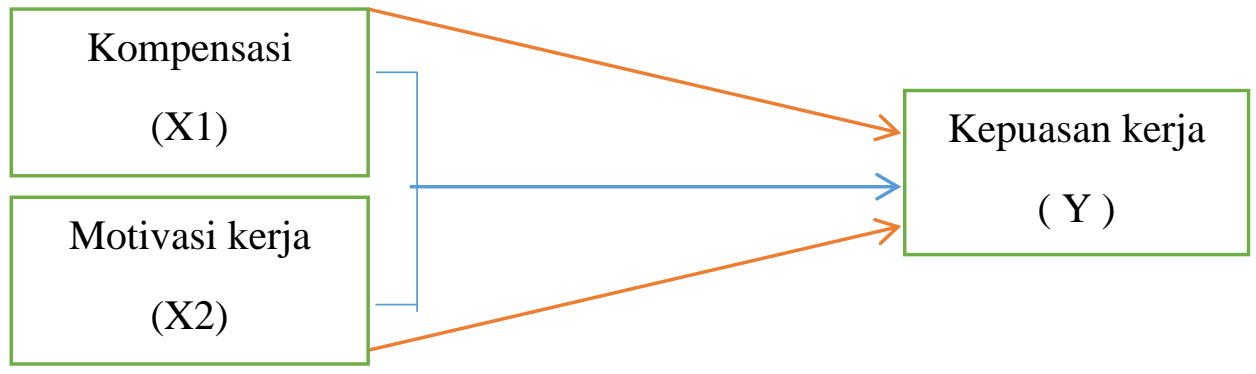

Gambar 1

Dari Kerangka Pemikiran yang telah dikemukakan di atas, maka hipotesis penelitian ini adalah sebagai berikut :

$\mathrm{H}_{1}$ : Di duga terdapat pengaruh positif dan signifikan kompensasi terhadap kepuasan kerja karyawan CV. Abata.

$\mathrm{H}_{2}$ : Di duga terdapat pengaruh positif dan signifikan motivasi kerja terhadap kepuasan kerja karyawan CV. Abata.

$\mathrm{H}_{3}$ : Di duga terdapat pengaruh positif dan signifikan kompensasi dan motivasi kerja secara bersamasama terhadap kepuasan kerja pegawai CV. Abata.

Instrumen penelitian berupa
kuisioner akan diuji coba menggunakan uji validitas dan uji reliabilitas. Uji validitas adalah istilah yang dipakai untuk menyatakan sejauh mana data yang ditampung pada suatu kuesioner akan mengukur apa yang ingin diukur. dalam pengujian validitas, untuk mencari harga korelasi dengan menggunakan rumus Korelasi Pearsons Product Moment (Sugiyono, 2017). Kriteria pengujiannya dilakukan dengan cara membandingkan rhitung dengan rable pada taraf $\alpha=0,05$, Jika hasil perhitungan ternyata $r_{\text {hitung }}>r_{\text {tabel }}$ maka butir instrument dianggap valid, sebaliknya jika rhitung< rtabel maka dianggap tidak valid (invalid), sehingga instrumen tidak dapat digunakan dalam penelitian. Berdasarkan hasil perhitungan ternyata diperoleh rhitung item pertanyaan variabel kompensasi, motivasi kerja dan kepuasan kerja lebih besar 0,312 ( $\left.r_{\text {tabel }}\right)$ sehingga semua item pertanyaan variabel kompensasi, motivasi kerja dan kepuasan kerja dinyatakan valid. Selanjutnya Uji reliabilitas adalah istilah yang dipakai untuk menunjukkan sejauh mana suatu hasil pengukuran relative konsisten apabila alat ukur kita gunakan berulang kali. Uji Reliabilitas yang digunakan dalam penelitian ini adalah metode Cronbach's Alpha. Berdasarkan hasil perhitungan diperoleh hasil perhitungan Cronbach's Alpha masing-masing variabel yaitu kompensasi sebesar 0,712, motivasi kerja sebesar 0,717, kepuasan kerja sebesar 0,744. Hal ini berarti instrumen penelitian ketiga variabel tersebut reliabel. 
Agar dapat diperoleh nilai yang tidak bias dan efisien dari persamaan regresi, maka dalam pelaksanaan analisis data harus memenuhi beberapa asumsi klasik sebagai berikut seperti uji normalitas yaitu untuk menguji apakah dalam sebuah model regresi, variabel bebas, variabel terikat atau keduanya mempunyai distribusi normal ataukah tidak. Model regresi yang baik adalah distribusi data normal atau mendekati normal. Hasil uji normalitas diperoleh bahwa data terdistribusi normal.

Uji multikolonieritas adalah untuk menguji apakah pada model regresi ditemukan adanya korelasi antara variabel independent. Jika terjadi korelasi, maka dinamakan terdapat problem multikolinieritas (Santoso,
2010). Hasil pengujian dinyatakan tidak terjadi multikolonieritas.

Uji heteroskedastisitas, tujuan uji non-heteroskedastisitas untuk menguji apakah dalam sebuah model regresi, terjadi ketidaksamaan varians dari residual dari suatu pengamatan ke pengamatan lain. Jika varians dari residual dari satu pengamatan ke pengamatan lain tetap, maka disebut Homoskedastisitas. Dan jika varians berbeda, disebut heteroskedastisitas (Santoso, 2010). Hasil pengujian dapat disimpulkan tidak terdapat gejala heteroskedastisitas dalam model regresi yang digunakan.

\section{Hasil Penelitian.}

Berdasarkan analisis regresi linear sederhana diperoleh hasil sebagai berikut :

Tabel 1

Hasil regresi linier sederhana $X_{1}$ Terhadap $Y$ Coefficients $^{a}$

\begin{tabular}{|c|c|c|c|c|c|}
\hline \multirow[b]{2}{*}{ Model } & \multicolumn{2}{|c|}{$\begin{array}{c}\text { Unstandardized } \\
\text { Coefficients }\end{array}$} & \multirow{2}{*}{\begin{tabular}{|c|}
$\begin{array}{c}\text { Standardized } \\
\text { Coefficients }\end{array}$ \\
Beta \\
\end{tabular}} & \multirow[b]{2}{*}{$\mathrm{T}$} & \multirow[b]{2}{*}{ Sig. } \\
\hline & $\mathrm{B}$ & Std. Error & & & \\
\hline $\begin{array}{ll}1 & \text { (Constant) } \\
& \text { Kompensasi }\end{array}$ & $\begin{array}{r}30,879 \\
, 237 \\
\end{array}$ & $\begin{array}{r}4,485 \\
, 180 \\
\end{array}$ & ,209 & $\begin{array}{l}6,885 \\
1,920 \\
\end{array}$ & $\begin{array}{l}, 000 \\
, 035 \\
\end{array}$ \\
\hline
\end{tabular}

a. Dependent Variable: Kepuasan kerja

Berdasarkan tabel hasil regresi linier sederhana diatas diperoleh hasil koefisien regresi untuk kompensasi sebesar 0,237 serta konstanta sebesar 30,879 , sehingga diperoleh persamaan

$$
\begin{aligned}
& \text { regresi linier sederhana sebagai } \\
& \text { berikut: } \\
& Y=a+b X \\
& Y=30,879+0,237 X_{1}
\end{aligned}
$$

Tabel 2

Hasil Regresi Linier Sederhana $X_{2}$ Terhadap Y Coefficients $^{a}$

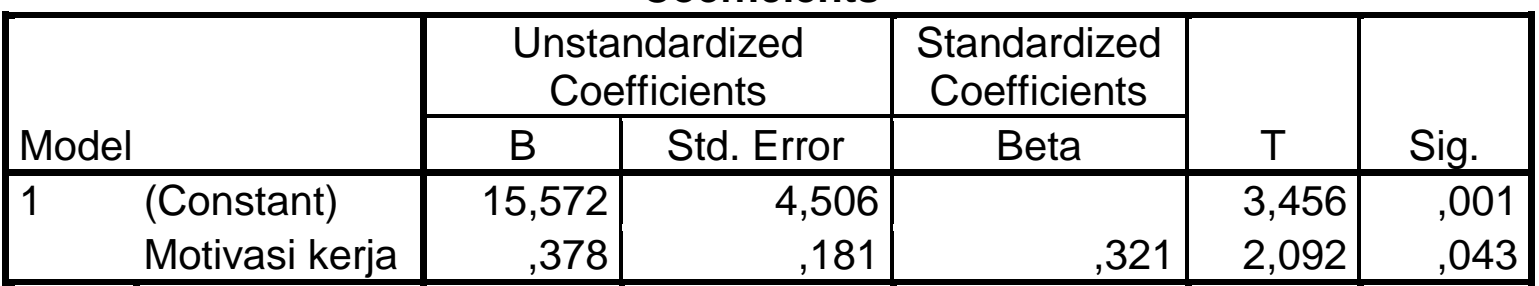

a. Dependent Variable: Kepuasan kerja 
Berdasarkan tabel hasil regresi linier sederhana diatas diperoleh hasil koefisien regresi untuk Motivasi kerja sebesar 0,378 serta konstanta sebesar 15,572 , sehingga diperoleh persamaan regresi linier sederhana sebagai berikut:

$\mathrm{Y}=\mathrm{a}+\mathrm{bX}$

$Y=15,572+0,378 X_{2}$

Tabel 3

Hasil Regresi Linier Berganda dan Uji t Coefficients $^{\mathrm{a}}$

\begin{tabular}{|c|c|c|c|c|c|c|}
\hline \multirow{2}{*}{\multicolumn{2}{|c|}{ Model }} & \multicolumn{2}{|c|}{$\begin{array}{l}\text { Unstandardized } \\
\text { Coefficients }\end{array}$} & \multirow{2}{*}{\begin{tabular}{|c|}
$\begin{array}{c}\text { Standardized } \\
\text { Coefficients }\end{array}$ \\
Beta \\
\end{tabular}} & \multirow[b]{2}{*}{$\mathrm{T}$} & \multirow[b]{2}{*}{ Sig. } \\
\hline & & $\mathrm{B}$ & Std. Error & & & \\
\hline & (Constant) & 21,850 & 5,674 & & 3,851 &, 000 \\
\hline & Kompensasi & ,299 & , 171 & ,264 & 1,746 & ,019 \\
\hline & Motivasi kerja & ,426 & , 178 & ,362 & 2,388 & ,022 \\
\hline
\end{tabular}

a. Dependent Variable: Kepuasan kerja

Berdasarkan tabel hasil regresi linier berganda dan $u j i ~ t ~ d i a t a s$ diperoleh hasil koefisien regresi untuk kompensasi sebesar 0,299 dan motivasi kerja sebesar 0,426 serta konstanta sebesar 21,850, sehingga diperoleh persamaan regresi linier berganda sebagai berikut:

$\mathrm{Y}=\mathrm{a}+\mathrm{b}_{1} \mathrm{X}_{1}+\mathrm{b}_{2} \mathrm{X}_{2}$

$Y=21,850+0,299 X_{1}+0,426 X_{2}$

Selanjutnya berdasarkan tabel hasil regresi linear berganda dan uji $t$ di atas untuk menguji pengaruh tiap variabel independen secara parsial terhadap variabel dependen dengan membandingkan nilai thitung dengan tabel.

Nilai tabel $\mathrm{N}=40-2=38$ dan alpha 0,05 adalah 1,685, sehingga uji $t$ sesuai tabel di atas adalah:

1. $X_{1}=$ thitung 1,746 sehingga $>$ tabel 1,685 dengan nilai signifikansi lebih besar dari 0,05 yaitu 0,019

2. $X_{2}=$ thitung 2,388 sehingga $>$ tabel 1,685 dengan nilai signifikansi lebih kecil dari 0,05 yaitu 0,022

\section{Tabel 4}

Uji F

ANOVA $^{a}$

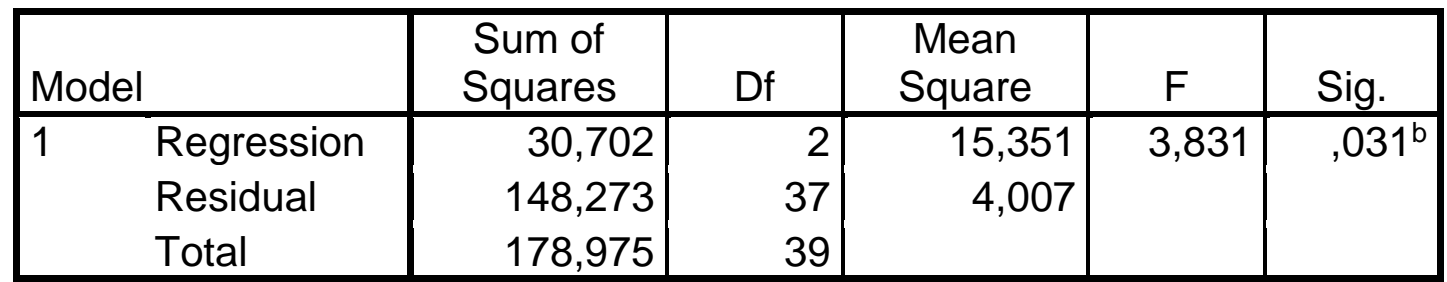

a. Dependent Variable: kepuasan kerja

b. Predictors: (Constant), kompensasi, motivasi kerja

Dari tabel di atas diperoleh nilai

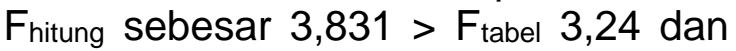
nilai signifikansi $0,031<\alpha 0,05$.

\section{Pembahasan}

Berdasarkan tabel 1 hasil regresi linier sederhana diatas diperoleh persamaan $\mathrm{Y}=30,879+0,237 \mathrm{X}_{1}$, konstanta sebesar 30,879 berarti jika kompensasi (X1) nilainya adalah 0 , 
maka kepuasan kerja nilainya sebesar 30,879 . Koefisien regresi variabel kompensasi (X1) sebesar 0,237 berarti jika nilai kompensasi mengalami kenaikan 1 satuan maka kepuasan kerja akan mengalami peningkatan sebesar 0,237.

Berdasarkan tabel 2 hasil regresi linier sederhana diatas diperoleh persamaan $Y=15,572+0,378 X_{2}$, konstanta sebesar 15,572 berarti jika motivasi kerja (X2) nilainya adalah 0 , maka kepuasan kerja nilainya sebesar 15,572. Koefisien regresi variabel motivasi kerja (X2) sebesar 0,378 berarti jika nilai motivasi kerja mengalami kenaikan 1 satuan maka kepuasan kerja akan mengalami peningkatan sebesar 0,378.

Berdasarkan tabel 3 hasil regresi linier berganda dan $u j i \mathrm{t}$ diatas diperoleh persamaan $\mathrm{Y}=21,850+$ $0,299 X_{1}+0,426 X_{2}$, konstanta sebesar 21,850 berarti jika kompensasi (X1) dan motivasi kerja (X2) nilainya adalah 0 , maka kepuasan kerja nilainya sebesar 21,850. Koefisien regresi variabel kompensasi (X1) sebesar 0,299 berarti jika nilai kompensasi mengalami kenaikan 1 satuan dengan asumsi nilai motivasi kerja tetap, maka kepuasan kerja akan mengalami peningkatan sebesar 0,299. Koefisien regresi variabel motivasi kerja (X2) sebesar 0,426 berarti jika nilai motivasi kerja mengalami kenaikan 1 satuan dengan asumsi nilai kompensasi tetap, maka kepuasan kerja akan mengalami peningkatan sebesar 0,426.

Selanjutnya berdasarkan tabel 3 hasil regresi linear berganda dan uji $t$ di atas diperoleh Nilai $t$ hitung kompensasi 1,746 > ttabel 1,685 dengan nilai signifikansi lebih kecil dari 0,05 yaitu 0,019 sehingga terima ha yaitu terdapat pengaruh positif dan signifikan kompensasi terhadap kepuasan kerja karyawan CV. Abata. Nilai t hitung motivasi kerja 2,388> ttabel
1,685 dengan nilai signifikansi lebih kecil dari 0,05 yaitu 0,022 sehingga terima ha yaitu terdapat pengaruh positif dan signifikan motivasi kerja terhadap kepuasan kerja karyawan CV. Abata.

Berdasarkan tabel 4 uji f di atas diperoleh Nilai $f$ hitung sebesar 3,831> $F_{\text {tabel }}$ 3,24 dan nilai signifikansi 0,031< a 0,05 sehingga terima ha yaitu terdapat pengaruh positif dan signifikan kompensasi dan motivasi kerja secara bersama-sama terhadap kepuasan kerja karyawan CV. Abata.

\section{Kesimpulan dan saran}

Dari analisis data dan pembahasan yang telah dilakukan maka kesimpulan dalam penelitian ini adalah sebagai berikut:

1. Terdapat pengaruh positif dan signifikan kompensasi terhadap kepuasan kerja pada karyawan CV. Abata.

2. Terdapat pengaruh positif dan signifikan motivasi kerja terhadap kepuasan kerja pada karyawan CV. Abata.

3. Terdapat pengaruh positif dan signifikan kompensasi dan motivasi kerja secara bersamasama terhadap kepuasan kerja pada karyawan CV. Abata.

Berdasarkan kesimpulan yang telah dikemukakan, maka saran dalam penelitian ini adalah sebagai berikut:

1. Diharapkan pimpinan perusahaan berusaha untuk dapat meningkatkan kompensasi kepada karyawan sesuai dengan kemampuan perusahaan agar kepuasan kerja pegawai dapat meningkat, misalnya dengan cara: menaikkan gaji, memberikan bonus, memberikan insentif, cuti, pujian dan lain lain.

2. Diharapkan pimpinan perusahanan berusaha untuk 
meningkatkan motivasi kerja karyawan dengan cara memberikan upah yang layak,memberikan kesempatan untuk maju, keamanan, tempat yang baik, pekerjaan yang wajar, pengakuan atas prestasi guna untuk menumbuhkan rasa kepuasan kerja pegawai.

3. Perlu dilakukan penelitian lanjutan dengan variabel penelitian lain yang dapat mempengaruhi kepuasan kerja karyawan CV. Abata.

\section{DAFTAR PUSTAKA}

Brahmasari, Ida Ayu. (2008). Pengaruh Motivasi Kerja, Kepemimpinan dan Budaya Organisasi Terhadap Kepuasan Kerja Karyawan dan Dampaknya pada Kinerja Perusahaan (studi kasus pada PT. Pei Hai International Wiratama Indonesia). Jurnal Manajemen dan Kewirausahaan Vol.10 No.2, 124-135.

Edison, Emron. Yohny Anwar dan Imas Komariyah. (2016). Manajemen Sumber Daya Manusia. Bandung: Alfabeta.

Hamali. (2018). Pemahaman Manajemen Sumber Daya Manusia. Jakarta: PT. Buku Seru.

Haryono, Siswoyo. dan Yasir Arafat. (2017). Effects of Organizational Culture and Work Motivation on Job Performance among the Private Universities' Fulltime Faculties in South Sumatera Province. Journal International Information Institute, 20(8A) , 5563-5575.
Hasibuan, Malayu. S. P. (2012). Manajemen Sumber Daya Manusia. Jakarta: Bumi Aksara.

Mangkunegara, Anwar Prabu (2005). Manajemen Sumber Daya Manusia Perusahaan, cetakan keenam. Bandung: PT. Remaja Rosdakarya.

Noor, Juliansyah. (2013). Penelitian IImu Manajemen. Jakarta: Kencana.

Purwanto, Ngalim. (2002). Administrasi dan Supervisi Pendidikan. Bandung: PT. Remaja Rosdakarya.

Robbins, Stepen P. (2002). Essentials of Organizational Behavior (Terjemahan), Edisi kelima. Jakarta: Erlangga.

Santoso, S. (2010). Buku Latihan SPSS Statistik Parametrik. Jakarta: PT. Elex Media Komputindo.

Sardiman, A. M. (2005). Interaksi dan Motivasi Belajar Mengajar. Jakarta: Pt. Raja Grafindo Persada.

Sudaryono. (2017). Metodologi Penelitian. 2017: PT. Raja Grafindo Persada.

Sugiyono. (2017). Metode Penelitian Kuantitatif, kualitatif, dan $R \& D$. Bandung: Alfabeta.

Sutrisno. (2017). Manajemen Sumber Daya Manusia. Jakarta: Kencana.

Wibowo. (2016). Manajemen Kinerja, edisi kelima. Jakarta: PT. Raja Grafindo Persada. 
Wilson, Bangun. (2012). Manajemen Sumber Daya Manusia. Jakarta: Erlangga.
Yusuf. (2015). Manajemen Sumber Daya Manusia di Lembaga Keuangan Syariah. Jakarta: PT. Raja Grafindo. 